\title{
Policy Windows: Sociopreneurship Activity Through Development of Turtle Breeding Ecotourism in Mapak Indah Beach Mey Susanti AS ${ }^{1}$, Johan Mashuri ${ }^{2}$ \\ Sekolah Tinggi Ilmu Administrasi Mataram, Prodi Ilmu Administrasi Negara ${ }^{1,2}$ Email: meysusanti.as@gmail.com ${ }^{1}$ \\ Email: johan.mashuri@yahoo.com²
}

(Received: May 15-2020; revised: Juny 10-2020; published: December 31-2020)

\begin{abstract}
Indonesia is one of the few countries in the world which becomes a natural habitat for turtles. However, like other countries, the Indonesia's turtle population are prone to extinction. All species of see turtles in Indonesia's waters are protected under the Government Regulation Number 7, 1999 concerning preservation of plant and animal species. Despite having the legal status, the turtle preservation is not fully comprehended and even ignored by the number of people. The development of turtle-based ecotourism is an alternative source of income. Mapak Indah Beach is considered to be a representative area for this ecotourism activity. However, finding from tourism and ecological activities shows no satisfactory results in combining the two activities. Sociopreneurship activities in the management of the Mapak Indah Beach turtle breeding ecosystem require an in-depth study to be able to access the policy windows of the Mataram City Government (the public agenda becomes the government's agenda). Strategic policies are: First, by opening discussion rooms which aim to accommodate ideas and control in discussing problems that exist in the public either through seminars, public discussions, as well as the public hearing. Second, increasing the coordination and role between stakeholders, increasing the capacity of facilities and infrastructure management, and increasing knowledge and skill of the community.
\end{abstract}

Keywords: Ecotourism; Turtle; Policy Windows; Sociopreneurship

\section{INTRODUCTION}

In addition to its beautiful nature, Indonesia has a variety of exotic animals, including turtles. Indonesia is one of the few countries in the world which becomes a natural habitat for turtles. There are seven species of turtles, and six out of which are available in Indonesian water. They are Green Turtle (Chelonia mydas), Scaly Turtle (Eretmochelys imbricata), LekangTurtle (Lepidochelys olivacea), Starfruit Turtle (Dermochelys coriacea), Flat Turtle (Natator depressus), and TempayanTurtle (Caretta caretta). However, like other countries, the Indonesia's turtle population are prone to extinction. In term of its population, the turtle habitat is in danger of extinction, both from the egg form to adulthood. Indonesia becomes a turtle habitat due to its location in the equator line. As a cold blooded reptile, turtle needs warm water in the equator area-like Indonesian water-which is preferred by turtles. Moreover, Indonesia is enriched with sea plants like corals which attract turtles to stay longer in Indonesian water because it is a favourite place for their food, the jellyfish. Several efforts in saving and 


\section{4 || Jurnal Ilmiah Ilmu Administrasi Publik: Jurnal Pemikiran dan Penelitian Administrasi Publik \\ Volume 1o Number 2, July-December 2020. Page 343-356}

conserving turtle have been done in order to preserve the ecosystem as a legacy to our succeeding generation. The conservation efforts include establishing turtle hatching station in variety of Indonesian waters and marking turtles as animal protected by law. All species of turtles in Indonesian water are protected under the Government Regulation Number 7, 1999 concerning preservation of plant and animal species. Eventhough it has legal status, some people are not fully aware, or even ignorant, of turtle preservation. It is reported that some regions in Indonesia are the place for turtles to lay eggs, such as the southern beach in West Java, southern beach of Bali, Central Kalimantan, southern beach of Lombok, East Java (Alas Purwo), Bengkulu, South Sulawesi (Cangke Island), Bintan Regency in Riau Island, Karimun Island, and Natuna island. However, we put little attention to the preservation of turtle ecosystem. The amount of trash in the coastal area which threaten the life of turtles, the illegal trade of turtles and their eggs, and the turtle extracting activity seriously hinder ecotourism development. Moreover, one female turtle only lays eggs once or twice every eight years by coming back to the place it originally hatched. Meanwhile, male turtle spends their whole life in the sea.

Mapak Indah beach is one of the tourism potential objects in Mataram yet not fully exposed to public. It is part of the administrative region of Tanjung Karang district, Sekarbela, Mataram city. Located in the coastal area in south Mataram, this tourism site is one of the tourist attractions which is very interesting to study for possible development. Mapak Indah beach has the characteristics preferred by turtles. It has wide enough black sand (10 to 30 meters), is relatively quiet, and has only a few buildings, excluding Mapak village. Initiated by H. Mahendra Irawan or better known as H. Awan, the community around the beach feels the need to protect this nearly extinct animal and starts doing breeding activity by shifting their shops into turtle breeding site. One female turtle usually produces at least 50 eggs. These eggs will be sorted later one by one in the sand hole and tagged with half a meter circle made of wire. After that, the hatchlings will be put into a small pond. When the hetchlings reach three months old, H. Awan will invite the people around Mapak Indah beach to see hatchlings release to their original habitat, the sea. When they reach adulthood, usually around June to August, those female turtles will comeback to Mapak Indah beach to lay dozen of their eggs. Based on this condition, in $2017 \mathrm{H}$. Awan and the Mapak people initiated the formation of Kelompok Pelestari Penyu Mapak (KP2M) or Mapak Turtle Preservaton Group under the guidance of Balai Pengelolaan Sumber Daya Pesisir dan Laut (BPSPL) Denpasar Wilayah Kerja NTB. Not only is Mapak Indah Beach a turtle breeding site, it is also a place with beautiful sunset overlooking the panorama of Gunung Agung, Bali. By far, the breeding activity done in Mapak Indah beach has run smoothly. It can be seen from the increasing number of female turtles which land, the number of eggs, and the number of hatchlings released to the sea. Apparently, turtle management as ecotourism needs a good coordination involving various stakeholders, not only the sociopreneurship, but also environmental institution (in this case, WWF), scholars, Corporate Social Responsibility (CSR), and political figures. That way, the expectation to develop general tourism by combining ecotourism and turtle-based ecology involving all stakeholders can be achieved. Given the importance of this sociopreneurship, a study should be 
conducted regarding the sociopreneurship how the potential of turtle breeding activities to decrease the illegal mistreatment of turtles and to access policy windows from Mataram government (Public agenda becomes government agenda), and this ecotourism activity is expected to fund the monitoring and cultivation of turtle. This phenomenon is the background of this research.

In describing the process for accessing the policy windows, the researcher used the development of John W. Kingdon's Multiple Streams Framework Model (Kingdon, 2001). Kingdon reconstructed that there were 3 (three) main streams in accessing policy windows, namely problems, proposals and politics streams. First, the problems stream is a stage of the agenda setting, why are certain social conditions questioned and made up as a policy agenda? Second, policy flows (proposals), namely ideas that emerge as solutions to policy problems. The process begins with the emergence of many ideas which are then combined, tested and searched for the best alternative. Third, the political stream (politics streams), namely the political situation that also encourages public attention, especially policy makers. The three flows will be met by a policy entrepreneur (PE) to be able to access / open a policy window. PE is a factor that comes from within or outside the government who is willing to invest time, energy, reputation, money, and employees to achieve the desired goals and values (Chrétien, 2012; Jenkins, 2005). Therefore, based on phenomena, as well as empirical and theoretical descriptions this study aims to describe the potential of sociopreneurship activity in accessing policy windows through development of turtle breeding ecotourism in Mapak Indah Beach, Tanjung Karang district, Sekarbela, Mataram, NTB.

\section{Figure 1.}

\section{Turtle Breeding Site in Mapak Indah Beach,}

\section{Sekarbela, Mataram}
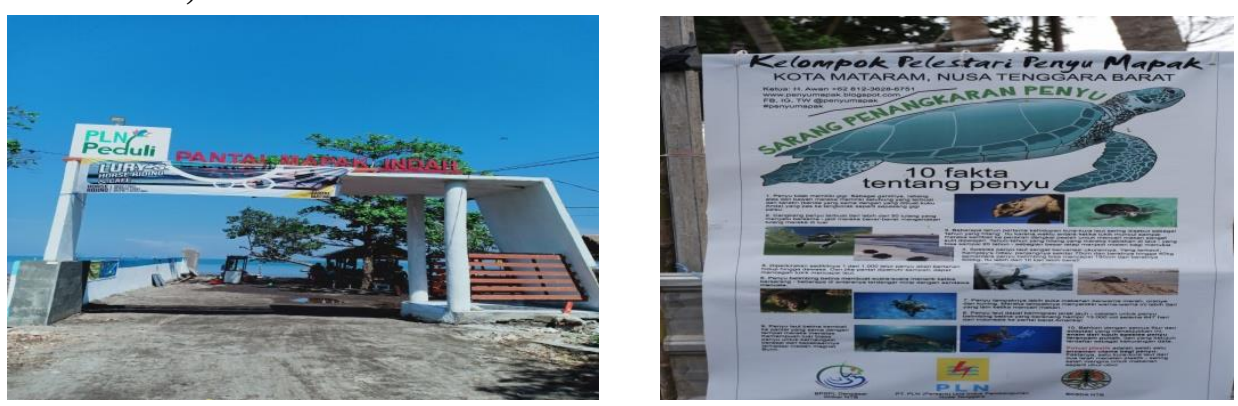

Source: Personal Document in March, 2020

\section{Sociopreneurship}

Members of the community or non-governmentorganisation play significant roles as democratic pillars to manifest resilient community capable of fighting for their people's rights. Non-government actors are individuals/groups who voluntarily aim to support public's activity and interest without taking any financial benefit. In social science, the existence of these actors can impact the emergence of sociopreneurshipconcept. 

346 | Jurnal Ilmiah Ilmu Administrasi Publik: Jurnal Pemikiran dan Penelitian Administrasi Publik
Volume 1o Number 2, July-December 2020. Page 343-356

Sociopreneurship, an abbreviation for social and entrepreneurship, is a term derived from entrepreneur domain. Originally, it is from the word 'social'which means society and 'entrepreneurship'which meansentrepreneur. Basically, sociopreneurship isunderstood as someone who knows and uses his enterpreneurship ability to make social change, specifically on welfare, education and health (Budi, 2007). It is in line with an explanation by Kim and Dees (2001) who stated that sociopreneurship is a combination building, and in social mission possessed great passion followed by discipline, innovation, and strength commonly occurring in the business world, or even in critical thinking (Listyorini, 2012). Hulgard (2010) formulated four main elements regarding sociopreneur concept as follow:

\section{Figure 2.}

\section{Four Main Element of Sociopreneurship according to Hulgard}

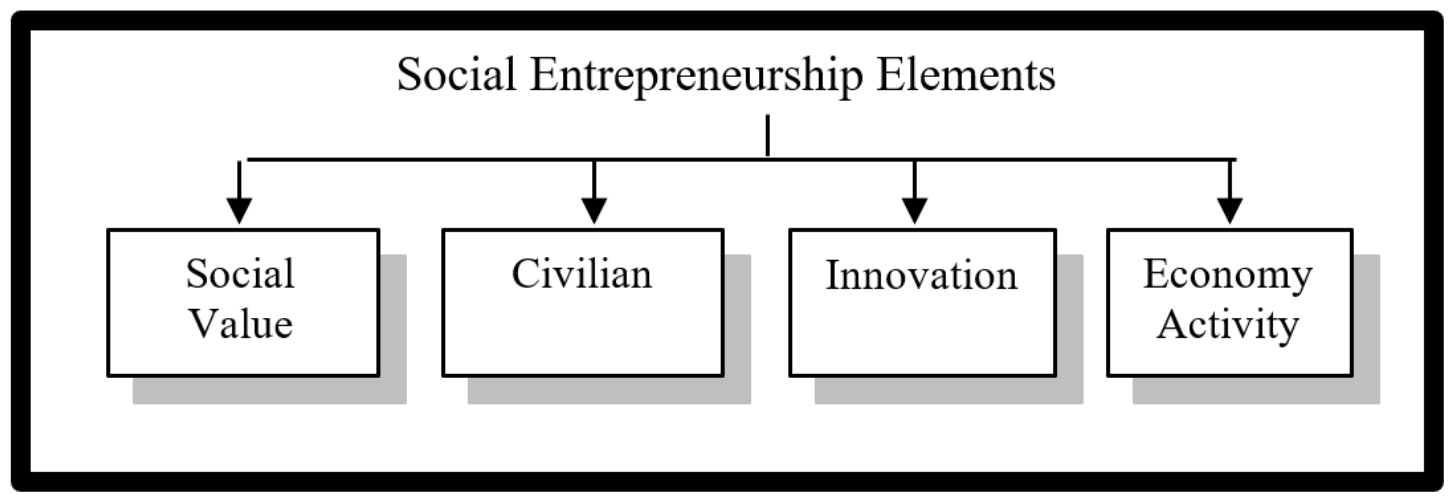

The connection between passion in business in public domain proven by sociopreneurship frequently linked to community empowerment will create a number of new concepts in public administration domain or developing government in the last decade. And awareness emerges regarding the lack of successful attempts of nation aparatures (in this case the government) as the main actor in solving public problems. A sociopreneurship usually has no limit in the domain in which he wants to choose to be part of. In fact, its existence can be distinguished with the government which focuses on health, infrastructure, education, economy, and so forth. Meanwhile, sociopreneurship focuses on the aim or ideology as can be understood from the limitations above. In public administration or government and social science in general, sociopreneurship is frequently connected to empowerment. In reality, discussions about empowerment emerge as the consequence of the failed attempt of development strategies which is later replaced by awareness to do social dimension development (Calves in Sanrego \& Taufik, 2016). In this domain does sociopreneurship play its role. 


\section{Ecotourism}

Ecotourism is considered as a kind of economically and environmentally sustainable effort for the community living within or around the conservation area (Bato et al., 2013). Ecotourism is also viewed as economical conservation-based alternative since it does not damage the nature. As mentioned in Law number 9, 1990 article 16, ecotourism isobject groups and tourism attractions, which is strengthen by Government Regulation Number 18 1994, as an activity to enjoy nature uniqueness in national park, forest, and natural tourism park. According to The International Ecotourism Society (TIES - The International Ecotourism Society, 2015), ecotourism is a trip to natural regions to preserve the environment, to support local community welfare, to involve interpretation, to take responsibility and education on living environment. There are three important components combined in this concept; nature conservation, local community empowerment, and living environment. This is for the sake of both the tourists and the local community.

The ecotourism principle is defined as a basis and guidance (in thinking, acting, and so forth) for every stakeholder involved in ecotourism (Sugiarto, 2016). According to Nurdin (2011), ecotourism basically has main principles, such as a. a developing tourism model responsible for natural regions managed with natural rules; $b$. To enjoy its beauty, it should involve educational element (EduTourism), understand and support toward conservation effort on natural resource; c. The existence of social, culture, and economy, such as the improvement of knowledge and income for local community.

UNCSD (United Nation Commission on Sustainable Development) mentioned that ecotourism is a kind of sustainable tourism which, 1) guarantee parallel, effective, and active participation 2) guarantee participation of local community, both those who agree and disagree with the community, area, and region development; 3 ) invite the community to be involved in controlling and preserving the resources. Next, Nugroho (2011) defined ecotourism as a small part of sustainable tourism activity and a tourism journey done professionally, trained, and consisted of educational element as economical source which concern itself on existing cultural heritage, participation. Moreover, it should increase local community income and make effort to do natural resource conservation and environment.

\section{Policy Windows}

Policy Windows is a condition which makes it possible to unite three flows of public policy in which actors like policy entrepreneur are needed to achieved it (Chrétien, 2012). Meanwhile, policy entrepreneur (PE) is an individual or organisation within or outside of government (not scholars) who identify, form, and direct the attention of othe policy actors to the problem and solution being studied to get benefit. Thus, the aim of the PE is an investment of money, time, and resources (Carrillo, 2007); (Chrétien, 2012); and (Perkmann M. Cross, 2003). 


\author{
348 | Jurnal Ilmiah Ilmu Administrasi Publik: Jurnal Pemikiran dan Penelitian Administrasi \\ Publik \\ Volume 1o Number 2, July-December 2020. Page 343-356
}

A study bridging environmental issues and public policy is highly required (Rose et al., 2017). Unfortunately, environmental activists are challenged by the shortness of open policy windows and the reality that those windows are open separately. Rose et al (2017) formulate four ways on how environment activists can access policy: 1) predicting (even creating) their own policy windows, 2) responding quickly to the opened policy window, 3) formulating research results relevant to the existing policy, and 4) keeping up when the policy windows are closed.

On the other hand, if the policy makers can predict the opening of policy window, then the planning will be easier and the existence of policy-preneur (one of which is activist) can be detected well (Guldbrandsson \& Fossum, 2009). The last two authors cited Kindon theories about important resources for policy-preneur, namely communication ability, position and expertise in the decision making system, political connection or negotiation skill, and the most important thing is resilience in promoting their ideas in any way and many forums, as well as investing big on resources for it.

\title{
METHOD
}

In a qualitative study, phenomenology is one of the perspectives which is commonly employed. The approach employs A Data Collecting Circle model from Creswell called Gaining Access and Making Rapport, by meeting and seeing the subject or informant directly. According to Cresswell cited in Kuswarno (2013), a good informant should have these criteria: "all individuals studied represent people who have experienced the phenomenon" (Creswell, 2015). The informants referred to in the research are the central actors as initiators and a number of individuals who are connected in the actor network in carrying out their core activities, in this case the Mataram City government and community members who live in the Mapak Indah coastal area. The data collection is conducted by: (1) Field Observation; (2) Unstructured indepth interview; and (3) Documentation. The data collection procedure is done by in-depth interview and is conducted after the interview which is recorded using tape recorder. As stated by Humphrey in Kuswarno (2013), in phenomenology study, data validation is carried out by sending the results of study to informant, and asking them to correct and add suggestions. 


\section{RESULT AND DISCUSSION}

Mataram city region which is only $0,30 \%$ from the total size of West Nusa Tenggara province has $61,30 \mathrm{Km}^{2}$ inland size, $56,80 \mathrm{Km}^{2}$ ocean size, and $9 \mathrm{~km}$ costal line. Mataram is a city with a small region from 10 regencies existing in West Nusa Tenggara.Moreover, Mataram is divided into 6 districts, 50 subdistricts, and 322 domains, as seen in the table below:

\section{Table 1.}

Region size, Number of Subdistricts and Domains based on District in Mataram 2015

\begin{tabular}{c|c|c|c|c} 
Kecamatan & $\begin{array}{c}\text { Jumlah } \\
\text { Kelurahan }\end{array}$ & $\begin{array}{c}\text { Jumlah } \\
\text { Lingkungan }\end{array}$ & $\begin{array}{c}\text { Luas Wilayah } \\
(\mathbf{K m} \mathbf{2})\end{array}$ & Persentase (\%) \\
\hline Ampenan & 10 & 55 & 9,46 & 15,43 \\
\hline Cakranegara & 10 & 72 & 9,67 & 15,77 \\
\hline Sekarbela & 5 & 35 & 10,32 & 16,84 \\
\hline Mataram & 9 & 55 & 10,76 & 17,55 \\
\hline Selaparang & 9 & 61 & 10,77 & 17,57 \\
\hline Sandubaya & 7 & 44 & 10,32 & 16,84 \\
\hline Jumlah & $\mathbf{5 0}$ & $\mathbf{3 2 2}$ & $\mathbf{6 1 , 3 0}$ & $\mathbf{1 0 0 , 0 0}$ \\
\hline
\end{tabular}

Source: BPS Kota Mataram, 2015

Demographic bonus is characterised by a condition where productive age population is bigger than nonproductive age. It is predicted that Indonesia experience the peak of demographic bonus in 2030. It means that productive batch (age 16-30 years) willappear in big numbers in 2025-2045. In this condition, productive age group will dominate. It implies that there will be many potential youths who can be involved in building national economy structure. As an effort to develop national economy, involving demographic bonus will increase the appearance of new young economic actors as sociopreneur agents.

The population of Mataram City matches the criteria of rapid population growth which is characterised by the condition that the number of births is much higher than the number of deaths. If the population of productive age can contribute to development, it will bring benefits to the community. One of the effective solutions to eradicate poverty and unemployment in the world is entrepreneurship (entrepreneurship). Through entrepreneurial activities, it is believed that it will be able to reduce the amount of poverty and is expected to open job opportunity.

Potential of Sociopreneurship Activity

A sociopreneur usually emerges from the presence of regional conditions and communities that are pinched in meeting the needs of daily life. It is also due to increasing global challenges. Today, young people have the potential if an access to creativity is provided by the surrounding social environment. Starting from 2006, H. Awan purchased this land on the edge of Mapak Indah beach to use for selling activities. He frequently found stranded turtles and scattered turtle eggs in the coastal area of Mapak Indah. The local community only works as fishermen and meets family needs by selling turtle eggs as an additional income.

Most of the local community understands the existence of turtle breeding management at Mapak Indah Beach. They also know that the activity of collecting turtle eggs is a wrong act, 


\author{
350 | Jurnal Ilmiah Ilmu Administrasi Publik: Jurnal Pemikiran dan Penelitian Administrasi \\ Publik \\ Volume 1o Number 2, July-December 2020. Page 343-356
}

meaning that this activity does not support conservation programs. However, these activities are still carried out due to economic needs. Additionally, in terms of income, most people do not feel much changes. The attitudes and behaviour of these people are of course influenced by the lack of knowledge about keeping and protecting this turtle ecosystem. The concept of a conservation strategy, which is protection, preservation and utilisation, is not yet understood by the community. They still think that conservation is only in the form of protective activities. The socialisation carried out by the managers through counselling has not reached them optimally, is very limited in nature, has not reached the wider community.

The public's respect for policies is a determining factor for the success of the policy. To encourage the success of policy implementation, community support is needed through participation in the implementation of public policies in the field. Community participation has a significant contribution to turtle conservation. This ignorant attitude of the community is caused by the low level knowledge. Henceforth, extension workers and assistants are needed to provide knowledge and skills so that community capacity can be improved. As for the behaviour of the community, which is not in accordance with the principles of turtle conservation, is due to the economic needs of the community. Thus, an alternative livelihood program is necessary to improve the community's economy, and the extraction of turtle eggs as an alternative to community income is no longer carried out.

The vision, mission and objectives of the development of the Mapak Indah Beach ecotourism area are the realisation of community welfare pursued through the development of turtle conservation-based ecotourism. This is manifested through the following missions: conducting activities to conserve turtle populations and their habitats, strengthening institutions at the area manager level, and improving the socioeconomic and cultural aspects of the local community. Human resources are an important component to support turtle conservation management. Up to now, there are about 50 managing human resources who are members of the Mapak Turtle Lovers Community (KP2M). Initiated by H. Awan, these human resources are divided into 3 (three) groups, namely: POKDARWIS (Tourism Awareness Group) which develops icons from Mapak Beach and preserves the view and manage parking locations and culinary areas; POKMASWAS (Community Supervisory Group) with its responsibility in terms of supervising, maintaining the harmony of ecosystems and nature. It already has a decree from the DKP of West Nusa Tenggara Province; and POKLAHSAR (Group of Processors and Marketers) which process and market shredded sea fish labeled BERUGAQ ELEN and already have a business license. However, of the 3 (three) groups that ran smoothly, only the POKDARWIS group.

The level of education is one of the factors affecting the capability of managers. Based on the level of education, most group members only have up to the elementary level education. Moreover, in group management, it is necessary to provide training for group members. Most of the group members have never attended training. Trainings such as technical training for turtle conservation for managers (Pokmaswas and Pokdarwis) as well as processing, packaging, and marketing training (Poklahsar) are very essential for them to attend. 
Facilities and infrastructure are an important factor in policy implementation. In order to support turtle conservation activities and ecotourism development, the procurement of which has been carried out in stages. Facilities and infrastructure for security activities needed are parking lots, guard posts, and supporting facilities such as culinary locations, water transportation, communication tools, area boundary signs, information boards and sea signs. Thus, the safety principles that are not yet available on Mapak Indah Beach are water transportation, area boundary signs and sea signs. Water transportation in the form of ships is used to transport officers in determining the location of the violations occurring. The available facilities for turtle preservation activities are an outdoor hatchery room, an indoor hatchery room, a hatchery room, a turtle care room, a pond for turtle maintenance, and a supporting facility for turtle breeding. The tool that is still needed is a tagging tool. Facilities and infrastructure for utilisation activities for ecotourism and research that are not yet available are information buildings, theater rooms/turtle museums as educational facilities for students, lodging, multipurpose halls, promotional materials, and results of previous research. The development of Facilities and infrastructure for utilisation activities is still being carried out in stages. Facilities and infrastructure have been realised through the existence of the Corporate Social Responsibility (CSR) program from PT. PLN (Persero) Tanjung Karang Area.

The use of the Mapak Indah Beach area for ecotourism activities has been running. Turtlebased ecotourism is a form of utilisation that has potential economic value. Turtle ecotourism can increase income and provide jobs for local communities. In addition, turtle-based ecotourism also provides benefits for tourists, namely as a means of education and increasing awareness to preserve nature and support its conservation. The purpose of tourists visiting Mapak Indah Beach is to enjoy the beauty of the beach with its sunset view, see hatchlings and turtles laying eggs and participate in hatchling release activities. In terms of utilising the Mapak Indah Beach area for research activities such as research topics related to turtles, nesting habitats, feeding habitats, ecotourism and communities around the area and turtle development, the access has been opened for researchers and students, both from Mataram and outside. However, turtle conservation management cannot be carried out by the manager alone. Turtle conservation management requires support from other stakeholders. 
352 | Jurnal Ilmiah Ilmu Administrasi Publik: Jurnal Pemikiran dan Penelitian Administrasi Publik

Volume 1o Number 2, July-December 2020. Page 343-356

Figure 2.

Sociopreneurship Activity Through Development of Turtle Breeding Development Mapak Indah Beach
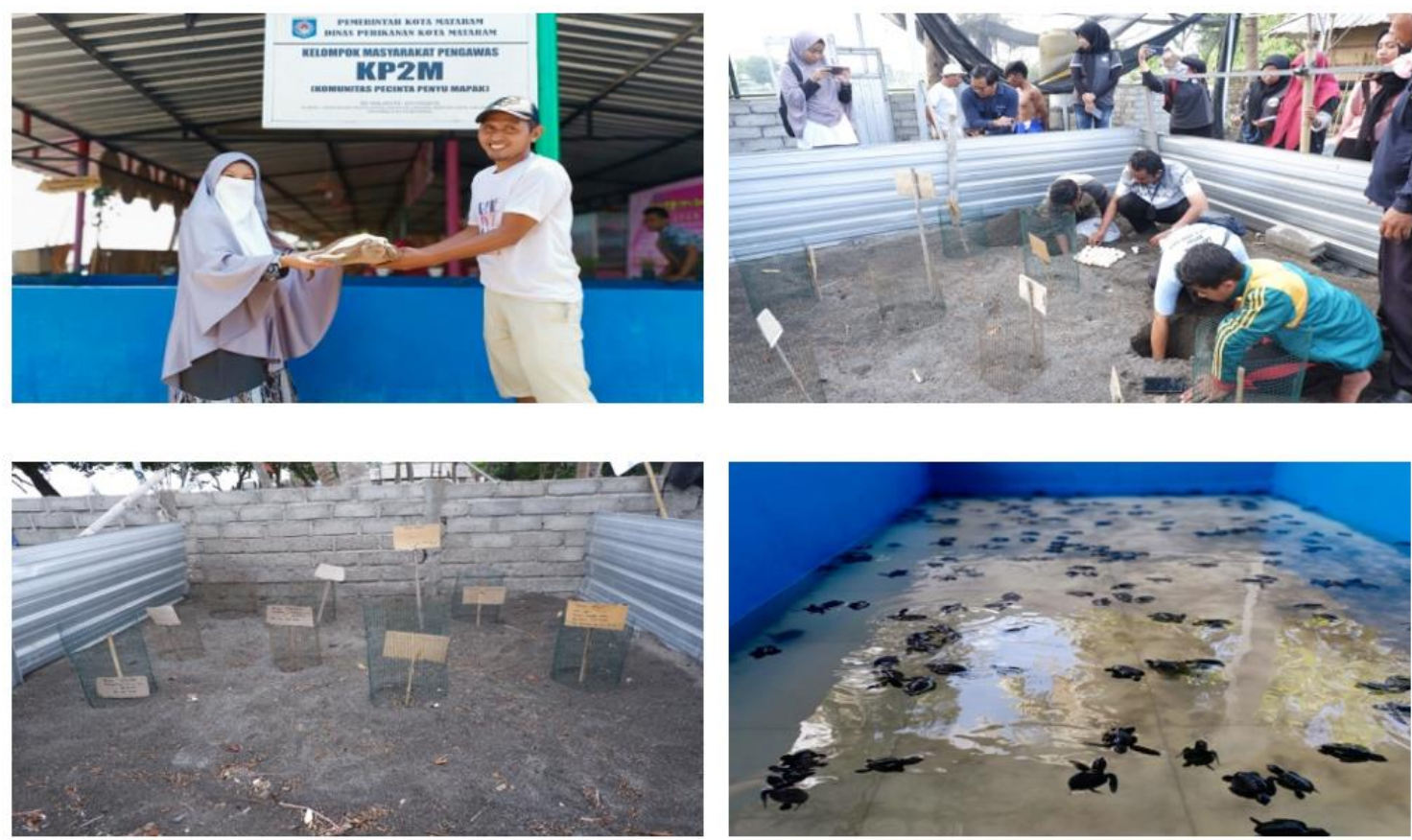

Source: Personal Document in July, 2020

Figure 3.

One of the Facilities and Infrastructures (Parking area) and Supporting Infrastructure (Culinary Location)
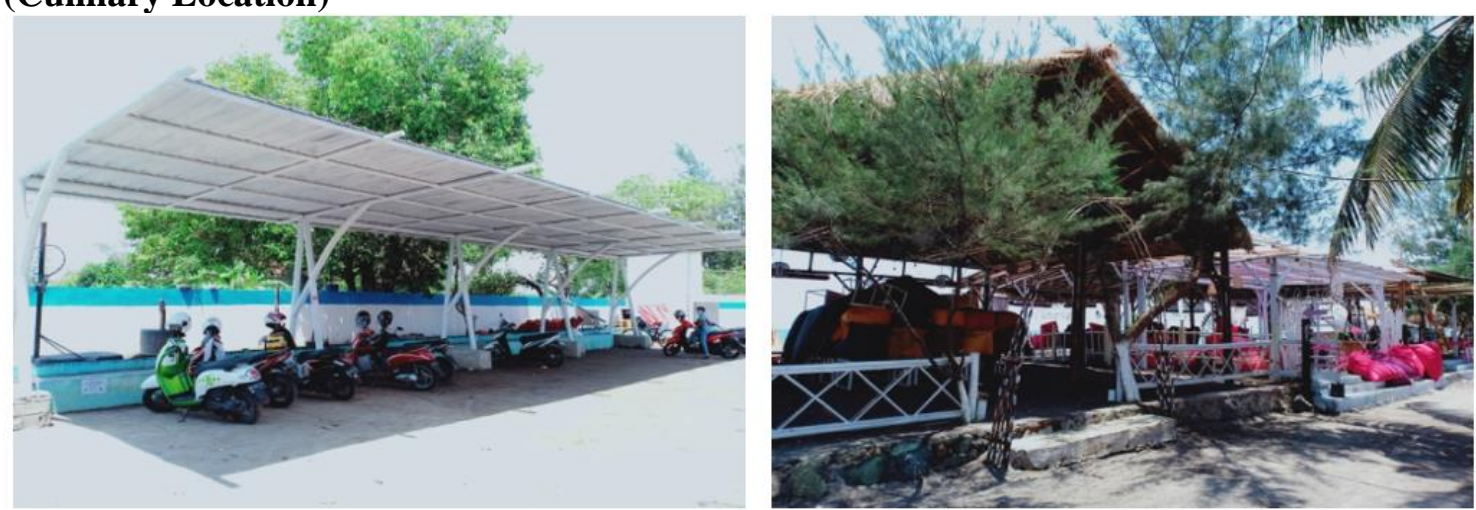

Source: Personal Document in July, 2020 


\section{The Idea of Developing a Turtle Conservation Ecotourism Site}

An alternative source of income for the Mapak Indah Beach area in Tanjung Karang Subdistrict, Sekarbela, through the development of turtle-based ecotourism, is considered an appropriate tool. In some areas where turtles land, the development of ecotourism like this has actually started to be done a lot. However, no one has succeeded in combining tourism and ecological activities with satisfactory value. In fact, this effort is very important seeing as the condition of the declining turtle population in Indonesia.

The turtle breeding at Mapak Indah Beach seems to be running effectively, as seen by increasing number of female turtles coming to lay eggs, increasing number of eggs and increasing number of hatchlings that have been successfully hatched and released back into the sea. Initially this breeding activity had no intention of being developed as a tourism attraction, this was purely done to save the turtle's habitat. However, over time these natural tourism activities appear to have potential economic benefits. Hence, the future plans are to increase tourism activities with more attention to the environment.

Turtle breeding activities as ecotourism need to be carried out in coordination with various stakeholders, because without which it is impossible to build ecotourism areas in nesting sites. By involving other stakeholders, the plan to develop tourism that combines economy and ecology can be fulfilled. To achieve this goal, the the central government is expected to play a full role given the need for firmer regulations to reduce the illegal turtle trade so that activities of mistreating turtles can be reduced, or even stopped. In fact, ecotourism activities can be a source of income for turtle breeding and breeding activities. The unique life cycle of a turtle has the potential to attract tourism. However, this activity must also be accompanied by awareness in preserving the environment.

In an effort to develop this turtle breeding ecotourism site, it requires three resources to assess and open policy windows, namely: (1) Problems, recognised the problems. Mataram city, with its rapid population growth, has a lower mortality rate compared to the birth rate. It is expected that it will have an impact on meeting the needs of daily life and the attitudes and behaviour of local people who still do not understand the concept of conservation strategies, namely protecting, preserving, and utilising. Behaviour that following the principles of sea turtle conservation is caused by economic needs; (2) Proposals, namely the availability of solutions. It is the ideas that have emerged as a solution to problems with the existence of alternative livelihood programs so that the local community's economy can increase. And the collection of turtle eggs as an alternative to community income is no longer carried out. In area management, it is carried out through institutional strengthening, and consequently, the socioeconomic and cultural of the local community improved; and (3) Politics, the existence of political conditions that support change. Handling sea turtles as ecotourism needs coordination involving all stakeholders. However, the current reality is that this has not been implemented. The development of turtle breeding ecotourism is a step to be able to access the policy windows of the Mataram City Government (the public agenda becomes the government's agenda).

Based on the previously conducted research, it was found that there is a non-simultaneous relationship between problems, proposals and politics. The conceptual depiction is as follows: 
354 | Jurnal Ilmiah Ilmu Administrasi Publik: Jurnal Pemikiran dan Penelitian Administrasi Publik

Volume 1o Number 2, July-December 2020. Page 343-356

\section{Figure 4.}

Multiple Streams Framework John W. Kingdon

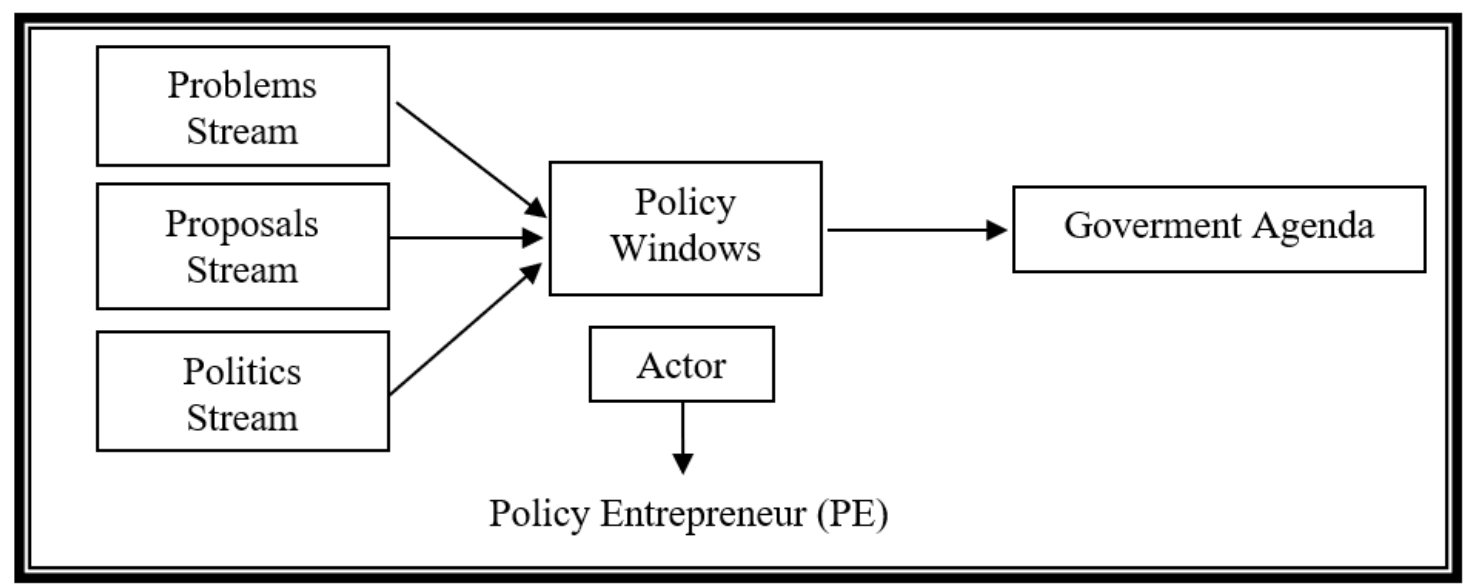

Source: Kingdon, 2001

The chart above explains that the more dominant force to open access to policy windows lies in the proposals stream. This flow seems to be able to provide encouragement and solutions to problems and the politics stream. Therefore, the policy entrepreneur (PE) must use current proposals to open policy windows rather than using other flows.

\section{CONCLUSION}

From this research, it was found that sociopreneurship through ecotourism development of turtle breeding in Mapak Indah Beach, Mataram, by applying sociopreneurship (Social Entrepreneurship) in accessing policy windows should be widely introduced. The community should provide public service independently regardless of government involvement. All this time we consider government as the most effective party in providing facilities and infrastructures for public and the most efficient in functioning the same way as private parties. The effort done by $\mathrm{H}$. Awan with social financial contribution for local community, mutualism, sustainability, and its impact to create service with economical value appears to be successful. This research implies that strategy policy to manage the ecosystem of turtle breeding in Mapak Indah beach can be done by: First, by opening discussion rooms which aim to accommodate ideas and control in discussing problems that exist in the public either through seminars, public discussions, as well as the public hearing. Second, increasing the coordination and role between stakeholders, increasing the capacity of facilities and infrastructure management, and increasing knowledge and skill of the community. 


\section{REFERENCES}

Bato, M., Yulianda, F., \& Fahrudin, A. (2013). Study of the benefits of marine conservation areas for the development of marine ecotourism: A case study in the marine conservation area of Nusa Penida, Bali. DEPIK Journal of Aquatic, Coastal and Fisheries Sciences, 2 (2). http://repository.ipb.ac.id/handle/123456789/66485

Budi, S. (2007). Data Mining Data Utilization Techniques for Business Purposes. Yogyakarta: Graha Ilmu.

Carrillo,I.L.(2007). The EU Presidency Agenda for Antiterrorism: A Multiple Stream Analysis. Belgium: University of Munster. https://www.researchgate.net/publication/277773086_The_EU_presidency_agenda_for_an titerrorism_a_multiple_streams_analysis

Chrétien, J. (2012). Policy Eentrepreneur: A Case Study of the 2002 G8 Summit in Kananaskis, Alberta. A Thesis Submitted to the College of Graduate Studies and Research In Partial Fulfillment of the Requirements For the Degree of Master of Arts In the Department of Political Studies University of Saskatchewan Saskatoon, Canada: University of Saskatchewan.

Creswell, J. W. (2015). Qualitative Research \& Design Research Choosing Among Five Approaches. In translation, Ahmad Lintang Lazuardi. Student Library, Yogyakarta.

Guldbrandsson, K., \& Fossum, B. (2009). An exploration of the theoretical concepts policy windows and policy entrepreneurs at the Swedish public health arena. Health Promotion International. https://doi.org/10.1093/heapro/dap033

Hulgård, L. (2010). Discourses of social entrepreneurship-Variations of the same theme? EMES European Research Network. Denmark: Roskilde University. Retrieved from http://base.socioeco.org/docs/wp_1 0-01_hulg_rd__web_.pdf

Jenkins, J. (2005). "Movers and shakers: A qualitative investigation on the role of policy entrepreneurs". McNair Scholars Research Journal, 1(1)

Kim, M., \& Dees, J. G. (2018). The Meaning of Social Entrepreneurship 1 , 2. In Case Studies in Social Entrepreneurship and Sustainability. https://doi.org/10.4324/9781351278560-5

Kingdon, J. W. (2001). Model of Agenda-Setting, with Applications. Law Review.

Kuswarno, E. (2013). Phenomenology Communication Research Methods: Concepts, Guidelines, and Research Examples. Bandung: Widya Padjadjaran.

Listyorini, H. (2012). Components and Impact of Social Entrepreneurship in the Efforts to 

356 | Jurnal Ilmiah Ilmu Administrasi Publik: Jurnal Pemikiran dan Penelitian Administrasi

Volume 10 Number 2, July-December 2020. Page 343-356

Revitalize the Lasem Batik Industry and Culture. Tourism Dynamics.

Nugroho, I. (2011). Ecotourism and Sustainable Development. Book. Student Library. Yogyakarta. 362 p.

Nurdin, M. (2011). Wonorejo Mangrove Forest Tourism: The Potential of Ecotourism and Edutourism in Surabaya. Marine Journal.

Perkmann M. Cross. (2003). Border Regions in Europe: Significance and Drivers of Regional Cross-Border Co-Operation. European Urban and Regional Studies. 10 (2): 153-171. doi: 10.1177 / 0969776403010002004.

Rose, D. C. (2017). Policy windows for the environment: Tips for improving the uptake of scientific knowledge. Environmental Science and Policy. https://doi.org/http://dx.doi.org/10.1016/j.envsci.2017.07.013

Sanrego, Y. D., \& Taufik, M. (2016). Fiqh Tamkin (Fiqh of Empowerment): Building Social Capital in Realizing Khairu Ummah. Jakarta: Qisthi Press. Retrieved from http://wisatabuku.com/fiqihtamkin/. http://wisatabuku.com/fiqihtamkin/

Sugiarto, E. (2016). Introduction to Ecotourism. Khitah Publishing. Yogyakarta..

TIES - The International Ecotourism Society. (2015). TIES Announces Ecotourism Principles Revision. Press Release. 